\title{
Absence of effects of dietary wheat bran on the activities of some key enzymes of carbohydrate and lipid metabolism in mouse liver and adipose tissue
}

\author{
BY JOHN C. STANLEY*, JACQUELINE A. LAMBADARIOS \\ AND ERIC A. NEWSHOLME \\ Department of Biochemistry, University of Oxford, \\ South Parks Road, Oxford OXI $3 Q U$
}

(Received 4 July 1985 - Accepted 1 November 1985)

\begin{abstract}
1. The effects of a $100 \mathrm{~g} / \mathrm{kg}$ dietary substitution of wheat bran on the body-weight gain, food consumption and faecal dry weight of mice given a high-sucrose diet and on the activities of some key enzymes of carbohydrate and lipid metabolism in liver and adipose tissue were studied.

2. Wheat bran had no effect on body-weight gain, food consumption or faecal dry weight.

3. Wheat bran had no effect on the activities of hepatic glucose-6-phosphate dehydrogenase $(E C$ 1.1.1.49), 6-phosphogluconate dehydrogenase ( $E C$ 1.1.1.44), malate dehydrogenase (oxaloacetate-decarboxylating) $\left(\mathrm{NADP}^{+}\right)(E C$ 1.1.1.40), ATP-citrate (pro-3S)-lyase (EC 4.1.3.8), pyruvate kinase $(E C 2.7 .1 .40)$ and fructose1,6-bisphosphatase $(E C 3,1.3 .11)$. The activity of hepatic 6-phosphofructokinase $(E C 2.7 .1 .11)$ increased but only when expressed on a body-weight basis.

4. Wheat bran had no effect on the activities of adipose tissue glucose-6-phosphate dehydrogenase, 6phosphogluconate dehydrogenase, malate dehydrogenase (oxaloacetate-decarboxylating) (NADP ${ }^{+}$), ATP-citrate (pro-3S)-lyase, hexokinase ( $E C 2.7 .1 .1), 6$-phosphofructokinase and pyruvate kinase.

5. These results suggest that unlike guar gum and bagasse, wheat bran does not change the flux through some pathways of lipogenesis in liver and adipose tissue when mice are given high-sucrose diets.
\end{abstract}

Dietary fibre has been defined as 'the plant polysaccharides and lignin which are resistant to hydrolysis by the digestive enzymes of man' (Trowell et al. 1976). Although this definition encompasses materials which are chemically very different (see Table 1 of Stephen \& Cummings, 1979), it is possible to distinguish two major classes of fibre, namely the gel-forming polysaccharides such as guar gum, pectin and gum tragacanth and the natural-fibre preparations such as wheat bran and bagasse. It has been shown that guar gum has effects on carbohydrate and lipid metabolism in man (Jenkins, 1979). Furthermore, in human subjects bagasse increases faecal excretion of acid steroids and fat (Walters et al. 1975) and raises the blood glucose concentration during an oral-glucose-tolerance test (Jefferys, 1974). These effects of guar gum and bagasse on carbohydrate and lipid metabolism in man prompted us to test the hypothesis that they have effects on hepatic metabolism. We found that guar gum increased (Stanley \& Newsholme, 1985a) and bagasse decreased (Stanley $\&$ Newsholme, 1985b) the activities of some key enzymes of carbohydrate and lipid metabolism in mouse liver.

Perhaps the best-studied type of dietary fibre is wheat bran, whose potential importance in human nutrition is emphasized by the finding that the absence of clinical ischaemic heart disease in middle-aged men, is associated with the consumption of a diet with a relatively-high cereal-fibre content (Morris et al. 1977). Wheat bran also has effects on carbohydrate and lipid metabolism in man. Wheat bran can improve glucose tolerance in healthy human subjects given a $50 \mathrm{~g}$ glucose meal (Jenkins et al. 1978).

While numerous studies, including those of Jenkins et al. (1975) and Kay \& Truswell (1977), failed to demonstrate any effects of wheat bran on total plasma cholesterol levels

* Present address: Nestlé Research Department, NESTEC Ltd, Avenue Nestlé 55, CH-1800 Vevey, Switzerland. 
in healthy human subjects, the studies of Bremner et al. (1975) and O'Moore et al. (1978) indicated that wheat bran might increase high-density-lipoprotein cholesterol. In rats wheat bran increases total plasma cholesterol and high-density-lipoprotein cholesterol (Asp et al. 1981). Wheat bran also increases the faecal excretion of fat and bile acids in human subjects (Cummings et al. 1976).

We have applied our experimental approach (Stanley \& Newsholme, 1985a,b) to a study of the effects of wheat bran on the metabolism of mouse liver. The results of this study are reported here.

\section{EXPERIMEN T A L}

\section{Animals, diets and feeding techniques}

Male adult BALB/c mice were obtained from OLAC 1976 Ltd, Bicester. Mice were housed individually in wire-mesh cages equipped with litter trays and were allowed access to Oxoid diet $41 \mathrm{~B}$ (Oxoid Laboratory Products, London) and water ad lib. The animals were maintained in a light-controlled room (lights on 06.00-20.00 hours) at a temperature of approximately $22^{\circ}$. At the beginning of the $28 \mathrm{~d}$ feeding period the mice were divided into two groups so that the control group had a mean body-weight of $21.4 \mathrm{~g}$ and the group given the wheat-bran diet had a mean body-weight of $21 \cdot 3 \mathrm{~g}$. All mice were $64 \mathrm{~d}$ old at this time.

Oxoid breeding diet powder was prepared by grinding Oxoid breeding diet pellets (Oxoid Laboratory Products) and putting the material through a sieve of mesh size $1.5 \mathrm{~mm}$; it contained $(\mathrm{g} / \mathrm{kg})$ : maize 100 , wheat 400 , maize germ 75 , soya bean 275 , fish meal 50 , molasses 25 , fat (tallow type) 12.5 , distillers' dried solubles 25 , minerals and vitamins $37 \cdot 5$, The high-carbohydrate control diet consisted of Oxoid breeding diet powder thoroughly mixed with $500 \mathrm{~g}$ sucrose $/ \mathrm{kg}$. Calculation showed that the control diet contained $(\mathrm{g} / \mathrm{kg})$ : carbohydrate 684, fat 30 , protein 253 and dietary fibre 18 .

Wheat bran was prepared by Prewett's, Horsham and purchased locally. The total dietary fibre content of this wheat-bran preparation is $480 \mathrm{~g} / \mathrm{kg}$ (Stephen \& Cummings, 1979). The fibre is made up of $(\mathrm{g} / \mathrm{kg})$ : moisture 94 , ash 64 , cellulose 86 , lignin 34 and non-cellulosic polysaccharide 355 . This fraction is composed of $(\mathrm{g} / \mathrm{kg})$ : pentose sugar 245 , hexose sugar 67 and uronic acid 43 . Wheat bran was shredded in an Osterizer liquidizer and material which passed through a sieve of mesh size $1.5 \mathrm{~mm}$ was used to prepare the diet. The experimental diet consisted of the control diet thoroughly mixed with $100 \mathrm{~g} / \mathrm{kg}$ wheat bran.

Feeding techniques have been described previously (Stanley \& Newsholme, 1985a). Throughout the feeding period the body-weight of each mouse was measured every morning immediately before giving the diet. During the second $7 \mathrm{~d}$ of the $28 \mathrm{~d}$ feeding period the food consumption and faecal dry weight output of each mouse was measured daily.

\section{Preparation of tissue extracts}

Methods for preparing liver extracts have been described previously (Stanley \& Newsholme, $1985 a$ ).

Epididymal fat pads were removed as rapidly as possible, weighed and divided into two portions. One portion was clamped between precooled $65 \mathrm{~mm}$ diameter plates and plunged into liquid nitrogen. When required these frozen adipose tissue samples were thawed as slowly as possible and used for the extraction and assay of hexokinase $(E C 2.7 .1 .1)$, 6-phosphofructokinase $(E C 2.7 .1 .11)$ and pyruvate kinase (EC 2.7.1.40). Preliminary experiments established that the activities of these enzymes were unaffected by freezing and thawing adipose tissue (results not shown). Fresh adipose tissue was kept on ice and used for the extraction and assay of glucose-6-phosphate dehydrogenase (EC 1.1.1.49), 6phosphogluconate dehydrogenase $(E C 1,1.1 .44)$, malate dehydrogenase (oxaloacetatedecarboxylating) $\left(\mathrm{NADP}^{+}\right)(E C 1.1 .1 .40)$ and ATP-citrate (pro-3S)-lyase (EC 4.1.3.8). 
Storage of adipose tissue samples in liquid $\mathrm{N}_{2}$ allowed more enzymes to be assayed in each epididymal fat pad.

Weighed samples of fresh or frozen adipose tissue were chopped with scissors and homogenized at room temperature in $10 \mathrm{vol}$. extraction medium using a glass homogenizer and five passes of a loose-fitting Teflon pestle. Fresh adipose tissue was extracted in $250 \mathrm{~mm}$-sucrose, $20 \mathrm{~mm}$-Tris hydrochloride, $1 \mathrm{~mm}$-magnesium chloride, $10 \mathrm{~mm}$-dithiothreitol, $100 \mathrm{~mm}$-potassium chloride (final $\mathrm{pH} \mathrm{7.6).} \mathrm{The} \mathrm{activities} \mathrm{of} \mathrm{glucose-6-phosphate}$ dehydrogenase, 6-phosphogluconate dehydrogenase and malate dehydrogenase (oxaloacetate-decarboxylating) $\left(\mathrm{NADP}^{+}\right.$) were stable in this medium for up to $6 \mathrm{~h}$ at $4^{\circ}$ (results not shown). ATP-citrate (pro-3S)-lyase began to lose activity after $30 \mathrm{~min}$ in this medium so it was assayed immediately after preparation of the extracts. Frozen adipose tissue was extracted in $250 \mathrm{~mm}$-sucrose, $50 \mathrm{~mm}$-glycylglycine, $10 \mathrm{~mm}$-dithiothreitol, $15 \mathrm{~mm}$-ethylene glycol-bis(aminoethylether)tetra acetate (EGTA) and $100 \mathrm{~mm}$-potassium fluoride (final

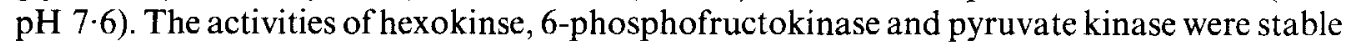
in this medium for up to $6 \mathrm{~h}$ at $4^{\circ}$ (results not shown). Two separate extraction media were required because different enzymes need different conditions for stability. Samples of all adipose tissue extracts were centrifuged at $4^{\circ}$ for two 2 -min periods at $12000 \mathrm{~g}$ in an Eppendorf bench centrifuge (model no. 3200). The clear layer between the fat layer and the pellet was used for enzyme assays and protein determinations.

\section{Enzyme and protein assays}

Methods for assaying liver enzymes have been described previously (Stanley \& Newsholme, 1985a). Adipose tissue glucose-6-phosphate dehydrogenase, 6-phosphogluconate dehydrogenase, malate dehydrogenase (oxaloacetate-decarboxylating) (NADP ${ }^{+}$), ATP-citrate (pro$3 S$ )-lyase, 6-phosphofructokinase and pyruvate kinase were assayed as described for the corresponding liver enzymes (Stanley \& Newsholme, 1985a). Adipose tissue hexokinase was assayed by measuring the rate of increase of absorbance at $340 \mathrm{~nm}$ due to the reduction of NADP ${ }^{+}$according to the method of Sugden \& Newsholme (1973) modified as follows. The assay medium contained: $100 \mathrm{mM}$-Tris hydrochloride, $10 \mathrm{mM}$-dithiothreitol, $100 \mathrm{~mm}$ potassium chloride, $5 \mathrm{~mm}$-magnesium chloride, $0.4 \mathrm{~mm}-\mathrm{NADP}{ }^{+}, 2.5 \mathrm{~mm}-\mathrm{ATP}, 10 \mathrm{~mm}-$ creatine phosphate, $100 \mu \mathrm{g}$ creatine kinase (EC 2.7.3.2), $10 \mu \mathrm{g}$ glucose-6-phosphate dehydrogenase, $1 \mathrm{~mm}$-glucose (final $\mathrm{pH} 7 \cdot 5$ ). Rates of $\mathrm{NADP}^{+}$reduction measured in the absence of glucose were used to correct for endogenous $\mathrm{NADP}^{+}$reduction. Changes in absorbance were measured at $25^{\circ}$ using a Gilford recording spectrophotometer (model no. 240). The final cuvette volume was $2 \mathrm{ml}$. Centrifuged adipose tissue extract was preincubated at $25^{\circ}$ for $10 \mathrm{~min}$ in an assay medium omitting substrate. For enzyme assays the reaction was started by the addition of substrate and for controls the reaction was started with distilled water. Enzyme assays and controls were carried out in duplicate.

Protein was assayed as described previously (Stanley \& Newsholme, 1985a).

\section{Statistical methods}

All results are expressed as mean values. The significance of the difference between two means was assessed using Student's $t$ test.

\section{RESULTS}

The effects of a $100 \mathrm{~g} / \mathrm{kg}$ dietary substitution of wheat bran on the food consumption and faecal dry weight of mice given a high-carbohydrate diet are shown in Table 1. The group of mice given the wheat-bran diet had a lower mean food consumption than the control group but this difference was not statistically significant. 
Table 1. The effect of $100 \mathrm{~g}$ wheat bran $/ \mathrm{kg}$ diet on the food consumption and faecal dry weight of mice

(Mean values for seven mice on the control diet and six mice on the wheat-bran diet)

\begin{tabular}{|c|c|c|c|c|}
\hline Diet. & Control & Wheat bran & Difference & $\operatorname{SED}(11 \mathrm{df})$ \\
\hline Body-wt (g) & $23 \cdot 9$ & $22 \cdot 4$ & $-1 \cdot 5$ & 0.83 \\
\hline \multicolumn{5}{|l|}{ Food consumption } \\
\hline$(\mathrm{g} / \mathrm{d})$ & $6 \cdot 4$ & $5 \cdot 5$ & -0.9 & $0 \cdot 45$ \\
\hline (g/d per kg body-wt) & 269 & 245 & -24 & 13.4 \\
\hline \multicolumn{5}{|l|}{ Faecal dry wt } \\
\hline$(\mathrm{g} / \mathrm{d})$ & $1 \cdot 2$ & $1 \cdot 1$ & $-0 \cdot 1$ & $0 \cdot 11$ \\
\hline (g/d per $\mathrm{kg}$ food consumption) & 193 & 198 & 5 & $17 \cdot 8$ \\
\hline
\end{tabular}

SED, standard error of difference.

Values for the wheat-bran diet were not significantly different from the corresponding values for the control diet (Student's $t$ test).

Table 2. The effect of $100 \mathrm{~g}$ wheat bran $/ \mathrm{kg}$ diet on the body-weight, final $24 \mathrm{~h}$ food consumption, liver weight and liver protein concentration of mice

(Mean values for seven mice on the control diet and six mice on the wheat-bran diet)

\begin{tabular}{|c|c|c|c|c|}
\hline Diet... & Control & Wheat bran & Difference & $\operatorname{SED}(11 \mathrm{df})$ \\
\hline Initial body-wt $(\mathrm{g})$ & 21.4 & $21 \cdot 3$ & $-0 \cdot 1$ & 0.42 \\
\hline Final body-wt (g) & $25 \cdot 6$ & $25 \cdot 0$ & -0.6 & 0.46 \\
\hline \multicolumn{5}{|l|}{ Food consumption } \\
\hline$(\mathrm{g} / \mathrm{d})$ & $7 \cdot 2$ & 6.7 & -0.5 & $0 \cdot 26$ \\
\hline (g/d per kg body-wt) & 281 & 270 & -11 & $9 \cdot 1$ \\
\hline \multicolumn{5}{|l|}{ Liver wt } \\
\hline (g) & 1.6 & 1.4 & $-0 \cdot 2^{* * *}$ & 0.04 \\
\hline (g/kg body-wt) & 62 & 57 & $-5^{* *}$ & $1 \cdot 3$ \\
\hline $\begin{array}{l}\text { Liver protein concentration } \\
\text { (mg/g liver) }\end{array}$ & 249 & 237 & 11 & 0.5 \\
\hline
\end{tabular}

SED, standard error of difference.

Values for the wheat-bran diet were significantly different from the corresponding values for the control diet (Student's $t$ test): ${ }^{* *} P<0 \cdot 01,{ }^{* * *} P<0 \cdot 001$.

The effect of a $100 \mathrm{~g} / \mathrm{kg}$ dietary substitution of wheat bran on the body-weight gain of mice given a high-carbohydrate diet is shown in Table 2. The group of mice given the wheat-bran diet had a lower mean body-weight at the end of the $28 \mathrm{~d}$ feeding period than the control group but this difference was not statistically significant.

The effects of a $100 \mathrm{~g} / \mathrm{kg}$ dietary substitution of wheat bran on the final $24 \mathrm{~h}$ food consumption, liver weight and liver protein concentration of mice given a high-carbohydrate diet is shown in Table 2. Preliminary experiments established that the activities of some hepatic lipogenic enzymes are directly proportional to the final $24 \mathrm{~h}$ food consumption of individual mice given high-carbohydrate diets (results not shown). The mean final $24 \mathrm{~h}$ food consumption of the group of mice given the wheat-bran diet was lower than that of the control group but this difference was not significant. This suggests that any changes in enzyme activity observed can be attributed to wheat bran rather than differences in the mean food consumptions of the two groups. The mice given the wheat-bran diet had a lower mean liver weight than the control group; this difference was statistically significant. 
Table 3. The effect of $100 \mathrm{~g}$ wheat bran $/ \mathrm{kg}$ on the activities of some mouse liver enzymes expressed on a wet weight basis (umol/min per $\mathrm{g}$ )

(Mean values for seven mice on the control diet and six mice on the wheat-bran diet)

\begin{tabular}{|c|c|c|c|c|}
\hline Diet. . & Control & Wheat bran & Difference & $\operatorname{SED}(11 \mathrm{df})$ \\
\hline $\begin{array}{l}\text { Glucose-6-phosphate dehydrogenase } \\
\text { (EC 1.1.1.49) }\end{array}$ & 0.5 & 0.5 & 0 & 0.06 \\
\hline $\begin{array}{l}\text { 6-Phosphogluconate dehydrogenase } \\
\text { (EC 1.1.1.44) }\end{array}$ & 1.8 & 1.9 & $0 \cdot 1$ & $0 \cdot 13$ \\
\hline $\begin{array}{l}\text { Malate dehydrogenase (oxaloacetate- } \\
\text { decarboxylating) }\left(\mathrm{NADP}^{+}\right)(E C 1.1 .1 .40)\end{array}$ & $14 \cdot 1$ & $13-4$ & $-0 \cdot 7$ & $1 \cdot 50$ \\
\hline $\begin{array}{l}\text { ATP-citrate }(\text { pro-3S)-lyase } \\
(E C 4.1 .3 .8)\end{array}$ & $2 \cdot 3$ & $2 \cdot 4$ & $0 \cdot 1$ & $0 \cdot 10$ \\
\hline $\begin{array}{r}\text { Pyruvate kinase } \\
(E C 2.7 .1 .40)\end{array}$ & 93.6 & $91 \cdot 8$ & $-1 \cdot 8$ & $8 \cdot 32$ \\
\hline $\begin{array}{l}\text { 6-Phosphofructokinase } \\
(E C 2.7 .1 .11)\end{array}$ & $2 \cdot 6$ & $2 \cdot 6$ & 0 & $0 \cdot 10$ \\
\hline $\begin{array}{l}\text { Fructose-1,6-bisphosphatase } \\
(E C \text { 3.1.3.11) }\end{array}$ & $18 \cdot 7$ & $19 \cdot 6$ & 0.9 & 0.99 \\
\hline
\end{tabular}

SED, Standard error of difference.

Values for the wheat-bran diet were not significantly different from the corresponding values for the control diet (Student's $t$ test).

Table 4. The effect of $100 \mathrm{~g}$ wheat bran $/ \mathrm{kg}$ diet on the activities of some mouse liver enzymes expressed on a protein basis ( $\mathrm{nmol} / \mathrm{min}$ per $\mathrm{mg}$ )

(Mean values for seven mice on the control diet and six mice on the wheat-bran diet)

\begin{tabular}{|c|c|c|c|c|}
\hline Diet... & Control & Wheat bran & Difference & $\operatorname{SED}(11 \mathrm{~d} \mathbf{f})$ \\
\hline $\begin{array}{l}\text { Glucose-6-phosphate dehydrogenase } \\
(E C 1.1 .1 .49)\end{array}$ & $2 \cdot 1$ & $2 \cdot 3$ & $0 \cdot 2$ & 0.20 \\
\hline $\begin{array}{l}\text { 6-Phosphogluconate dehydrogenase } \\
\text { (EC 1.1.1.44) }\end{array}$ & $7 \cdot 5$ & 7.9 & 0.4 & 0.67 \\
\hline $\begin{array}{l}\text { Malate dehydrogenase (oxaloacetate- } \\
\text { decarboxylating) }\left(\mathrm{NADP}^{+}\right)(E C 1.1 .1 .40)\end{array}$ & $57 \cdot 3$ & $56 \cdot 6$ & $-0 \cdot 7$ & 6.54 \\
\hline $\begin{array}{l}\text { ATP-citrate }(\text { pro-3S)-lyase } \\
(E C 4.1,3.8)\end{array}$ & $9 \cdot 5$ & 9.9 & 0.4 & 1.29 \\
\hline $\begin{array}{r}\text { Pyruvate kinase } \\
(E C 2.7 .1 .40)\end{array}$ & 378 & 392 & 14 & $44 \cdot 0$ \\
\hline $\begin{array}{l}\text { 6-Phosphofructokinase } \\
(E C 2.7 .1 .11)\end{array}$ & $10 \cdot 4$ & $11 \cdot 0$ & 0.6 & 0.60 \\
\hline $\begin{array}{l}\text { Fructose-1,6-bisphosphatase } \\
(E C 3.1 .3 .11)\end{array}$ & $75 \cdot 2$ & 82.8 & $7 \cdot 6$ & 3.99 \\
\hline
\end{tabular}

SED, standard error of difference.

Values for the wheat-bran diet were not significantly different from the corresponding values for the control diet (Student's $t$ test).

A variety of units have been used to express hepatic enzyme activities in nutritional studies (Freedland, 1967). In the present work hepatic enzyme activities have been expressed on a liver-fresh-weight basis (Table 3), on a liver-protein basis (Table 4) and on a body-weight basis (Table 5). Expressing adipose tissue enzyme activities on a fresh weight or body-weight basis is unreliable because of the diffuse nature of the tissue and its variable triglyceride content. Therefore, adipose-tissue-enzyme activities have been expressed on a tissue-protein 
Table 5. The effect of $100 \mathrm{~g}$ wheat bran $/ \mathrm{kg}$ diet on the activities of some mouse liver enzymes expressed on a body-weight basis (umol/min per $\mathrm{kg}$ )

(Mean values for seven mice on the control diet and six mice on the wheat-bran diet)

\begin{tabular}{|c|c|c|c|c|}
\hline Diet... & Control & Wheat bran & Difference & $\operatorname{SED}(11 \mathrm{df})$ \\
\hline $\begin{array}{l}\text { Glucose-6-phosphate dehydrogenase } \\
(E C 1.1 .1 .49)\end{array}$ & 32 & 31 & -1 & $3 \cdot 6$ \\
\hline $\begin{array}{l}\text { 6-Phosphogluconate dehydrogenase } \\
\text { (EC 1.1.1.44) }\end{array}$ & 115 & 105 & -10 & $8 \cdot 2$ \\
\hline $\begin{array}{l}\text { Malate dehydrogenase (oxaloacetate- } \\
\text { decarboxylating) }\left(\mathrm{NADP}^{+}\right)(E C 1.1,1,40)\end{array}$ & 879 & 765 & -114 & $100 \cdot 1$ \\
\hline $\begin{array}{l}\text { ATP-citrate }(\text { pro-3S)-lyase } \\
(E C 4.1 .3 .8)\end{array}$ & 145 & 134 & -11 & $19 \cdot 7$ \\
\hline $\begin{array}{l}\text { Pyruvate kinase } \\
(E C 2.7 .1 .40)\end{array}$ & 5820 & 5198 & -622 & $379 \cdot 6$ \\
\hline $\begin{array}{l}\text { 6-Phosphofructokinase } \\
(E C 2.7 .1 .11)\end{array}$ & 161 & 148 & $-13^{*}$ & $4 \cdot 2$ \\
\hline $\begin{array}{l}\text { Fructose-1,6-bisphosphatase } \\
(\text { EC 3.1.3.11) }\end{array}$ & 1161 & 1112 & -49 & $51 \cdot 3$ \\
\hline
\end{tabular}

SED, standard error of difference.

Values for the wheat-bran diet were significantly different from the corresponding values for the control diet (Student's $t$ test) : ${ }^{*} P<0.05$.

Table 6. The effect of $100 \mathrm{~g}$ wheat bran $/ \mathrm{kg}$ diet on the activities of some mouse adipose tissue enzymes expressed on a protein basis ( $\mathrm{nmol} / \mathrm{min}$ per $\mathrm{mg}$ )

(Mean values for seven mice on the control diet and six mice on the wheat-bran diet)

\begin{tabular}{|c|c|c|c|c|}
\hline Diet. & Control & Wheat bran & Difference & $\operatorname{SED}(11 \mathrm{df})$ \\
\hline $\begin{array}{l}\text { Glucose-6-phosphate dehydrogenase } \\
(E C 1.1 .1 .49)\end{array}$ & 91.8 & $91 \cdot 6$ & $-0 \cdot 2$ & 11.75 \\
\hline $\begin{array}{l}\text { 6-Phosphogluconate dehydrogenase } \\
\text { (EC 1.1.1.44) }\end{array}$ & 56.8 & 55.6 & $-1 \cdot 2$ & $10 \cdot 29$ \\
\hline $\begin{array}{l}\text { Malate dehydrogenase (oxaloacetate- } \\
\text { decarboxylating) }\left(\mathrm{NADP}^{+}\right)(E C 1.1 .1 .40)\end{array}$ & 97.9 & $96 \cdot 0$ & $-1 \cdot 9$ & 22.03 \\
\hline $\begin{array}{l}\text { ATP-citrate }(\text { pro-3S)-lyase } \\
(E C 4.1 .3 .8)\end{array}$ & $39 \cdot 8$ & 38.6 & $-1 \cdot 2$ & $8 \cdot 18$ \\
\hline $\begin{array}{l}\text { Pyruvate kinase } \\
(E C 2.7 .1 .40)\end{array}$ & 295 & 341 & 46 & $31 \cdot 26$ \\
\hline $\begin{array}{l}\text { 6-Phosphof ructokinase } \\
(E C 2.7 .1 .11)\end{array}$ & 11.6 & $10 \cdot 5$ & $-1 \cdot 1$ & 1.49 \\
\hline $\begin{array}{l}\text { Hexokinase } \\
(E C 2.7 .1 .1)\end{array}$ & 11.6 & $12 \cdot 8$ & $1 \cdot 2$ & 1.71 \\
\hline
\end{tabular}

SED, standard error of difference.

Values for the wheat-bran diet were not significantly different from the corresponding values for the control diet (Student's $t$ test).

basis only (Table 6). The results presented in these tables show that, with a single exception, a $100 \mathrm{~g} / \mathrm{kg}$ dietary substitution of wheat bran had no statistically-significant effects on the activities of any of the adipose tissue or liver enzymes studied. The exception was hepatic 6-phosphofructokinase activity which, when expressed on a body-weight basis, was significantly lower in the group given the wheat-bran diet (see Table 5). 


\section{DISCUSSION}

In the mouse, liver and adipose tissue are important sites of fatty acid synthesis in vivo (Hollands \& Cawthorne, 1981). In adipose tissue, glucose is the major source of carbon for fatty acid synthesis (Denton et al. 1977) and key reactions of glycolysis are catalysed by hexokinase, 6-phosphofructokinase and pyruvate kinase. In the liver, glycogen is an important precursor for fatty acid synthesis (Salmon et al. 1974) and the key enzymes of glycolysis, 6-phosphofructokinase and pyruvate kinase, catalyse reactions of this pathway. In liver, 6-phosphofructokinase activity is opposed by fructose-1,6-bisphosphatase activity. In both tissues the NADPH required for fatty acid synthesis is provided by the key enzymes of the pentose phosphate pathway, glucose-6-phosphate dehydrogenase and 6phosphogluconate dehydrogenase (Martin \& Denton, 1970; Krebs \& Eggleston, 1974) and by malate dehydrogenase (oxaloacetate-decarboxylating) (NADP ${ }^{+}$), a key enzyme of the pyruvate-malate cycle (Martin \& Denton, 1970; Rognstad \& Katz, 1979). ATP-citrate (pro-3S)-lyase, another key enzyme of the pyruvate-malate cycle, generates the acetyl-CoA needed for fatty acid synthesis in the cytoplasm of both tissues (Martin \& Denton, 1970; Lowenstein, 1971).

In the present work, wheat bran failed to change the activities of nearly all the previously-mentioned key enzymes of carbohydrate and lipid metabolism in mouse liver and adipose tissue. This contrasts with guar gum and bagasse which, when tested in the same experimental system, increased and decreased respectively the activities of several of these enzymes in liver (Stanley \& Newsholme, 1985 a, b). However, the lack of effect of wheat bran is, perhaps, not unexpected since in previous studies where the metabolic effects of the same quantity of different types of dietary fibre have been compared, wheat bran generally had either the smallest effect or no effect at all. Thus, while both guar gum and wheat bran improve glucose tolerance in healthy human subjects given a $50 \mathrm{~g}$ glucose meal, the effect is greatest for guar gum (Jenkins et al. 1978). Similarly, guar gum lowers serum cholesterol levels in healthy human subjects while wheat bran does not (Jenkins et cl. 1975).

Nevertheless, the absence of an effect of wheat bran on the activities of the previouslymentioned enzymes reported here has important implications for the studies we have described elsewhere (Stanley \& Newsholme, 1985a,b). In all these experiments we have examined the effects of a $100 \mathrm{~g} / \mathrm{kg}$ dietary substitution of fibre on enzyme activity. When $100 \mathrm{~g} / \mathrm{kg}$ of the control diet is substituted by fibre the other components of the diet are inevitably diluted. Consequently it could be argued that the effects of guar gum or bagasse that we observed previously (Stanley \& Newsholme, 1985a,b) were due not to the presence of fibre per se but rather to a dilution of other components of the diet by fibre. The fact that a $100 \mathrm{~g} / \mathrm{kg}$ dietary substitution of wheat bran has no effect on the activities of the enzymes studied, demonstrates that dilution of other components of the diet by fibre cannot explain the effects of guar gum and bagasse that we observed. Therefore, the wheat-bran study reported here represents an important control for the guar gum and bagasse studies.

We have previously suggested several possible mechanisms whereby guar gum and bagasse might exert their effects on hepatic metabolism (Stanley \& Newsholme, 1985a,b). A further possible mechanism can now be suggested which may help to explain the lack of effect of wheat bran on enzyme activity. The extent to which different types of dietary fibre are metabolized by bacteria in the caecum and colon is variable. Thus when pectin is added to the normal diet of human subjects it cannot be recovered from the faeces (Cummings et al. 1979). By contrast, between $30 \%$ and $40 \%$ of the dietary fibre of wheat bran could be recovered in the faeces of human subjects (Southgate et al. 1976). Among the products of bacterial metabolism of fibre are the short-chain fatty acids (acetic, propionic and butyric acids) which can be absorbed by the rectal mucosa of human subjects 
(McNeil et al. 1978). Pectin, therefore, may be a better source of short-chain fatty acids for the tissues than wheat bran. Short-chain fatty acids can be metabolized directly by the liver and hence hepatic metabolism would be modified less by wheat bran and more by pectin. Alternatively, utilization of short-chain fatty acids by the epithelial cells of the colon could be greater when pectin is given. As a result glucose oxidation by the epithelial cells would be inhibited more (Roediger, 1980) and lactate release would be greater. Since lactate is an excellent precursor for fatty acid synthesis in the liver (Salmon et al. 1974), pectin would modify hepatic metabolism more than wheat bran. Thus, the extent and nature of bacterial metabolism of wheat bran, bagasse and guar gum could provide an explanation for their very different effects on hepatic metabolism.

The authors wish to acknowledge the generous financial support provided by the Wellcome Trust.

\section{REFERENCES}

Asp, N. G., Bauer, H. G., Nilsson-Ehle, P., Nyman, M. \& Oste, R. (1981). British Journal of Nutrition 46, $385-393$. Bremner, W. F., Brooks, P. M., Third, J. L. H. C. \& Lawrie, T. D. V. (1975). British Medical Journal ii, 574.

Cummings, J. H., Hill, M. J., Jenkins, D. J. A., Pearson, J. R. \& Wiggins, H. S. (1976). American Journal of Clinical Nutrition 29, 1468-1473.

Cummings, J. H., Southgate, D. A. T., Branch, W. J., Wiggins, H. S., Houston, H., Jenkins, D. J. A., Jivraj, T. \& Hill, M. J. (1979). British Journal of Nutrition 41, 477-485.

Denton, R., Bridges, B., Brownsey, R., Evans, G., Hughes, W. \& Stansbie, D. (1977). Biochemical Society Transactions 5, $894-900$.

Freedland, R. A. (1967). Journal of Nutrition 91, 489-495.

Hollands, M. A. \& Cawthorne, M. A. (1981). Biochemical Journal 196, 645-647.

Jefferys, D. B. (1974). Proceedings of the Nutrition Society 33, 11A-12A.

Jenkins, D. J. A. (1979). Lancet ii, 1287-1290.

Jenkins, D. J. A., Newton, C., Leeds, A. R. \& Cummings, J. H. (1975). Lancet i, 1116-1117.

Jenkins, D. J. A., Wolever, T. M. S., Leeds, A. R., Gassull, M. A., Haisman, P., Dilawari, J., Goff, D. V., Metz, G. L. \& Alberti, K. G. M. M. (1978). British Medical Journal i, 1392-1394.

Kay, R. M. \& Truswell, A. S. (1977). British Journal of Nutrition 37, 227-235.

Krebs, H. A. \& Eggleston, L. V. (1974). Advances in Enzyme Regulation 12, 421-434.

Lowenstein, J. M. (1971). Journal of Biological Chemistry 246, 629-632.

McNeil, N. I., Cummings, J. H. \& James, W. P. T. (1978). Gut 19, 819-822.

Martin, B. R. \& Denton, R. M. (1970). Biochemical Journal 117, 861-877.

Morris, J. N., Marr, J. W. \& Clayton, D. G. (1977). British Medical Journal ii, 1307-1314.

O'Moore, R. R., Flanagan, M., McGill, A. R., Wright, E. A., Little, C. \& Weir, D. G. (1978). British Medical Journal i, 1213.

Roediger, W. (1980). Gut 21, 793-798.

Rognstad, R. \& Katz, J. (1979). Journal of Biological Chemistry 254, 11969-11972.

Salmon, D. M. W., Bowen, N. L. \& Hems, D. A. (1974). Biochemical Journal 142, 611-618.

Southgate, D. A. T., Branch, W. J., Hill, M. J., Drasar, B. S., Walters, R. L., Davies, P. S. \& McLean Baird, I. (1976). Metabolism 25, 1129-1135.

Stanley, J. C. \& Newsholme, E. A. (1985a). British Journal of Nutrition 53, 215-222.

Stanley, J. C. \& Newsholme, E. A. (1985b). British Journal of Nutrition 54, 415-420.

Stephen, A. M. \& Cummings, J. H. (1979). Gut 20, 722-729.

Sugden, P. H. \& Newsholme, E. A. (1973). Biochemical Journal 134, 97-101.

Trowel1, H. C., Southgate, D. A. T., Wolever, T. M. S., Leeds, A. R., Gassull, M. A. \& Jenkins, D. J. A. (1976). Lancet i, 967.

Walters, R. L., McClean Baird, I., Davies, P. S., Hill, M. J., Drasar, B. S., Southgate, D. A. T., Green, J. \& Morgan, B. (1975). British Medical Journal ii, 536-538. 